\title{
The Influence of Teacher Certification on the Performance of Elementary School Teachers in Gorontalo Province, Indonesia
}

\author{
Siti Asiah Tjabolo
}

Dr, IAIN Sultan Amai Gorontalo, Gorontalo, Indonesia, asiahpido@iaingorontalo.ac.id

\section{Herwin}

Dr, Universitas Negeri Yogyakarta, Yogyakarta, Indonesia, herwin89@uny.ac.id

The purpose of this study was to determine the performance of certified elementary school teachers and the influence of teacher certification on the performance of elementary school teachers in Gorontalo Province. This study uses a quantitative approach through the comparative design of two groups of data. The data group in question is data from a sample of teachers who already have an educator certificate, as well as other data groups derived from a sample of teachers who do not yet have an educator certificate. The sample of this study was 179 teachers taken by simple random sampling. Data is collected through observation. The data analysis technique used is descriptive statistics and inferential statistics through the $t$ test. The results of the study show that there is a significant influence of teacher certification on the performance of elementary school teachers in Gorontalo Province. The results of the study found that teachers who had an educator certificate had better performance than teachers who did not yet have an educator certificate. The teacher certification program has a positive impact on Gorontalo Province.

Keywords: teacher certification, teacher performance, schools, teachers, influence

\section{INTRODUCTION}

The teacher is the most influential aspect in the implementation of education. The quality of teachers is an effort to improve the quality of the education system (Malkab et al., 2015). Teacher's profession is positioned as the front and center guard in the implementation of the learning process. Related to that, the teacher's performance is always an interesting material to be studied and analyzed, both in organizing the learning process and in evaluating student learning outcomes on an ongoing basis. Teacher performance is one of the important factors that must be considered in an effort to improve the quality of education (Wenno, 2017). The performance of a teacher is more directed at professionals whose work or activities require expertise, skills or skills 
that meet quality standards, or certain norms that require professional education. That way, government policy in terms of meeting the level of professionalism of teachers who are experts in their fields must receive recognition of expertise or the so-called legality of teacher certification.

Teacher certification is an effort to improve teacher quality (Harjantoa et al., 2017). Teacher professionalism is measured based on the competency approach, meaning: a professional teacher must possess and master pedagogical competencies, personality competencies, social competencies and professional competencies. The focus is more on the low professionalism of teachers in the learning process, which leads to a decline in the quality of education. Teacher performance is seen as part of teacher competence related to professional competence, pedagogical competence, social competence and personal competence. If teacher competency is low, teacher performance will also be low (Arifin, 2013).

The phenomenon of teacher certification in Gorontalo Province still cannot be clearly explained about how teacher performance is certified and whether the certification has an impact on teacher performance especially in classroom learning activities. In addition, there have been no empirical findings, especially in Gorontalo Province, which are able to explain the location of differences between the performance of teachers who already have a certificate and teachers who do not yet have a certificate. Teacher certification is one way to improve teacher performance and quality (Nurmalia \& Kusumawardhani, 2017). Teacher certification must also be approved about salary increases received by teachers who have certification certificates (Chetty, Friedman, \& Rockoff 2014; Hanushek 2011; Jackson, Rockoff, \& Staiger 2014). Although Loeb \& Page (2000) explained that it was difficult to explain about the increase in teacher salaries to increase student achievement.

The challenges that need to be considered are the problems in the professional value of a teacher, the higher value, the professional value that can be done through accountability for the client. However, this might be difficult because they have many clients (VillegasReimers, 2003). Although there are teacher licenses such as large-scale educator certificates in Indonesia, there is also evidence to show that these licenses are not a guarantee to ensure high-performing teachers, because the more competent are those who are younger and relatively less credentials, although most of they are not licensed to teach (Suryadi, Rasjidi \& Budimansyah, 2017). Recognized teachers are still found to have negative responses related to their competence and professional competence (Haryanto et al., 2016). Some of these conditions form the basis for conducting empirical studies related to the influence of teacher certification on the performance of elementary school teachers in Gorontalo Province. The purpose of this study was to determine the performance of certified elementary school teachers and the influence of teacher certification on the performance of elementary school teachers in Gorontalo Province.

\section{METHOD}

This study uses a quantitative approach through the comparative design of two groups of data. The data group in question is data from a sample of teachers who already have an 
educator certificate, as well as other data groups derived from a sample of teachers who do not yet have an educator certificate. Participants in this study were 179 elementary school teachers randomly selected. Of the total participants consisting of 91 teachers who have educator certificates and 88 other teachers who do not yet have educator certificates. The determination of participants in both groups was also randomly selected Data collection was carried out using an observation guidance instrument. Observations were made to measure three performance indicators in learning. The three indicators of teacher performance evaluation used in learning include: pre-learning, core learning activities, and closing activities. The observer in this study was supervisors in each school. This was done so as not to disrupt the organizational system in every school and region. In detail, the measuring indicator of teacher performance appraisal in classroom learning activities is presented in Table 1 below.

Table 1

Component of Teacher Performance Assessment

\begin{tabular}{|c|c|}
\hline \multirow[t]{2}{*}{ Pre-learning } & Check student readiness \\
\hline & Conduct apperception activities \\
\hline \multicolumn{2}{|l|}{ Core learning activities } \\
\hline \multirow{4}{*}{$\begin{array}{l}\text { Mastery of subject } \\
\text { matter }\end{array}$} & Demonstrate mastery of learning material \\
\hline & Associate material with other relevant knowledge \\
\hline & Deliver the material clearly and in accordance with the learning hierarchy \\
\hline & Linking material to the reality of life \\
\hline \multirow{6}{*}{$\begin{array}{l}\text { Learning approach / } \\
\text { strategy }\end{array}$} & Carry out learning in accordance with the competencies (objectives) to be achieved \\
\hline & Carry out coherent learning \\
\hline & Mastering the class \\
\hline & Carry out contextual learning \\
\hline & Carry out learning that allows positive habits to grow \\
\hline & Do the learning due to the planned time allocation \\
\hline \multirow{3}{*}{$\begin{array}{l}\text { Use of learning } \\
\text { resources / learning } \\
\text { media }\end{array}$} & Use media influenceively and efficiently \\
\hline & Produce interesting messages \\
\hline & Involving students in media use \\
\hline \multirow{3}{*}{$\begin{array}{l}\text { Learning that triggers } \\
\text { and maintains student } \\
\text { involvement }\end{array}$} & Foster active participation of students in learning \\
\hline & Demonstrate an open attitude towards student responses \\
\hline & Growing the joy and antusism of students in learning \\
\hline \multirow{2}{*}{$\begin{array}{l}\text { Assessment of learning } \\
\text { processes and results }\end{array}$} & Monitor learning progress during the process \\
\hline & Conduct final assessment in accordance with the competencies (objectives) \\
\hline \multirow[t]{2}{*}{ Use of language } & Use spoken and written language clearly, well, and correctly \\
\hline & Deliver the message in the appropriate style \\
\hline \multirow[t]{2}{*}{ Closing Activities } & Reflect or make a summary by involving students \\
\hline & $\begin{array}{l}\text { Carry out follow-up by providing direction, or activities, or assignments as part of } \\
\text { remedies / enrichments }\end{array}$ \\
\hline
\end{tabular}

Table 1 shows that there are 3 measuring indicators (pre-learning, core learning activities, and closing activities) which are spread over 24 items of observation. The results of these measurements will be processed to compare the performance of teachers who have educator certificates and the performance of teachers who do not have an educator certificate. The data analysis technique used is descriptive statistics and inferential statistics through the t test. As a guideline in conducting data analysis, the statistical hypothesis is needed as follows.

$\mathrm{H}_{0}: \mu_{1} \leq \mu_{2}$ 
$\mathrm{H}_{1}: \mu_{1}>\mu_{2}$

with,

$\mu_{1}$ : performance of teachers who have educator certificates

$\mu_{2}$ : performance of teachers who do not have an educator certificate

To decide the conclusion of the analysis results, the criteria used are $\mathrm{H}_{0}$ rejected if the $t$ observation is greater than $t$-table or $p$-sig smaller than $\alpha 0.05$.

\section{FINDINGS}

\section{Description of Teacher's Performance}

Teacher performance is measured based on 3 measuring indicators (pre-learning, core learning activities, and closing activities) which are spread over 24 items of observation. In this study there are two groups of teacher performance data, namely performance data for groups of teachers who already have educator certificates and others are data of groups of teachers who do not yet have an educator certificate. The first finding described in the results of this study is teacher performance data for groups of teachers who have educator certificates. Descriptively, the findings data can be observed in Table 2 below.

Table 2

Performance Score Data and Student Learning Outcomes of Teachers Who Have Educator Certificates

\begin{tabular}{lcc}
\hline Statistics & Teacher Performance & Student Learning Outcomes \\
\hline Minimum & 60 & 65 \\
\hline Maximum & 91 & 95 \\
\hline Mean & 82,31 & 84,6 \\
\hline Std. Deviation & 5,41 & 5,5 \\
\hline Variance & 29,3 & 31,1 \\
\hline
\end{tabular}

The first finding related to teacher performance was obtained from a group of teachers who had an educator certificate totaling 91 teachers. Based on the research data that has been obtained it can be explained that the range of data scores is between 60 as the minimum score up to 91 as the maximum score. Another thing that was found was an mean value of 82.31, a standard dviation of 5.41 and a variance of 29.30 . Based on the descriptive statistical data, it can be explained that basically the performance scores of teachers who have educator certificates are at a high score. This is based on the average score of performance that has reached 82.31 or a high score. This means that the performance of teachers who have a legal educator certificate is satisfactory and must be maintained in the future.

Another thing that can be explained is the score of student learning outcomes. The results showed that student learning outcomes had a high average score of 84.6. The average score is very satisfying for the current achievements. The second finding described in the results of this study is teacher performance data for groups of teachers who do not yet have an educator certificate. Descriptively, the findings data can be observed in Table 3 below. 
Table 3

Teacher Performance Score Data and Stundent Learning Outcomes that Does Not Have an Educator Certificate

\begin{tabular}{lcc}
\hline Statistics & Teacher Performance & Student Learning Outcomes \\
\hline Minimum & 54 & 57 \\
\hline Maximum & 88 & 90 \\
\hline Mean & 77,55 & 79,5 \\
\hline Std. Deviation & 6,72 & 6,6 \\
\hline Variance & 45,23 & 44,7 \\
\hline
\end{tabular}

The second finding related to teacher performance was obtained from a group of teachers who did not yet have an educator certificate totaling 88 teachers. Based on the research data that has been obtained it can be explained that the range of data scores is between 54 as the minimum score up to 88 as the maximum score. Another thing that was found was an average value of 77.55, a standard dviation of 6.72 and a variance of 45.23. In the aspect of student learning outcomes obtained research results that indicate an average score that is quite high at 79.5 . The average score still needs to be improved when compared with the results that have been achieved in a group of teachers who have been certified educators.

Based on descriptive statistical data for the second finding, it can be explained that the performance of teachers who do not have an educator certificate is basically not maximal and still low when compared to the performance of teachers who have an educator certificate. This can be seen from the average score which is still at the value of 77.55. Descriptively, it can be explained that educator certificates have an influence on teacher performance.

Another thing that can be described in the results of this study is the distribution of teacher performance based on 3 measuring indicators used in performance appraisal. The three indicators are pre-learning, core learning activities, and closing activities. Data from the three indicators are also described based on the performance comparison of teachers who already have educator certificates with performance data of groups of teachers who do not have an educator certificate. In detail the presentation of the data is presented in Figure 1 as follows.

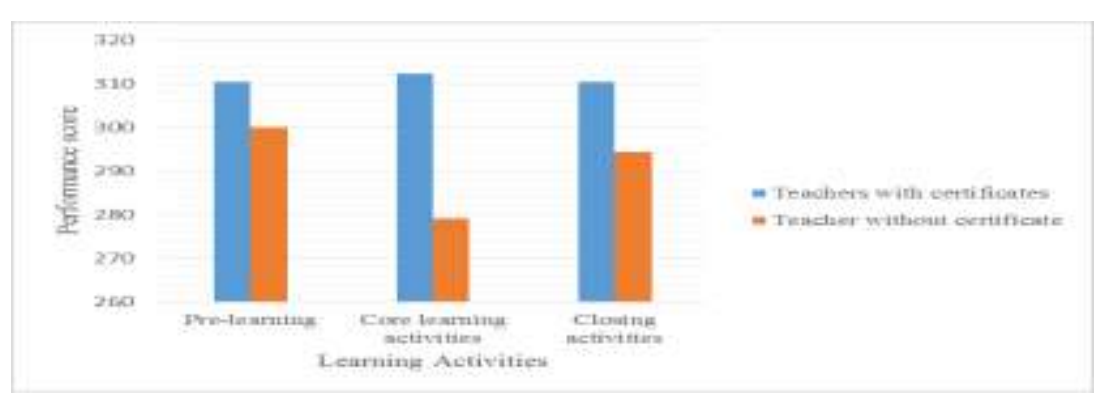

Figure 1

Distribution of Teacher Performance Based on Three Measuring Indicators 
Figure 1 presents information about the distribution of teacher performance scores in terms of the three measuring indicators, namely: pre-learning, core learning activities, and closing activities. In addition, data distribution also provides information regarding the comparison of teacher performance scores that already have educator certificates with performance scores of teachers who do not yet have an educator certificate. Based on the presentation, it can be explained that the performance score of teachers who already have an educator certificate is higher for the three measuring indicator components.

The findings in Figure 1 show that teachers who already have an educator certificate tend to master the pre-learning indicators, core learning activities, and closing activities. The most striking difference can be seen in the core learning activities indicator. In this indicator, the difference in performance between the two groups is very different. Descriptively the performance of teachers who have higher educator certificates than teachers who do not have an educator certificate.

\section{Hypothesis Testing Results}

In addition to using descriptive statistics, inferential statistics were used in this study with the intention of testing hypotheses. Hypothesis testing is done by t test to test significantly the differences in the performance of teachers who have educator certificates with the performance of teachers who do not have an educator certificate. The results of the $t$ test from the two independent data groups can be seen in Table 4 as follows.

Table 4

Inferential Test Results

\begin{tabular}{ll}
\hline Test result & Value \\
\hline t-observation & 5,226 \\
\hline Df & 177 \\
\hline$p$-value & .000 \\
\hline Meand difference & 4.76 \\
\hline Std. Error Difference & 0.91 \\
\hline
\end{tabular}

Based on the results of testing inference statistics using the independent group $t$ test, the t-observation value is obtained at 5.226. If the results are controlled by testing criteria, it can be explained that t-observation (5.226) is greater than t-table (1.653) in df 177 with alpha 0.05 . This is the basis for concluding that $\mathrm{H}_{0}$ is rejected. The same is found in the p-value aspect. Based on the results of the analysis obtained $p$ value 0,000 or smaller than alpha 0.05 . Thus, the inferential test results conclude that the conclusions related to $\mathrm{H}_{0}$ is rejected and conclusions related to $\mathrm{H}_{1}$ is accepted. This underlies the conclusion that the performance of teachers who have educator certificates is significantly better than the performance of teachers who do not have an educator certificate. It can also be directly stated that the teacher certification program held in Gorontalo Province has had a positive influence on improving the performance of elementary school teachers in Gorontalo Province. 


\section{DISCUSSION}

The results of this study obtained several findings, namely the first is the performance of elementary school teachers who already have educator certificates in Gorontalo Province are at a high value. This is an achievement that needs to be maintained in order to develop the quality of education, especially in Gorontalo Province. Teacher performance is a very important thing to get attention, because teacher performance has a direct impact on the success of their students. Teachers are a very important element in the education system. For this reason, the development of teacher quality is an effort to develop the education system for the better. The teacher can develop the personal and intellectual characteristics of his students through his professional development (Almeida, 2017). Therefore to obtain quality student output, the quality of the teacher must also be good and one of the indicators of teacher quality is its performance in the learning process in the classroom.

In the implementation of education, students are always the main target to be developed. Organizing education is said to be successful when students are able to achieve learning goals in the form of achievements and good learning outcomes. This is certainly very related to the performance of teachers in the classroom. Schacter (2005) revealed that the quality of teacher performance as the most important variable in improving student achievement. The influence of teachers on student achievement has proven to be greater than a variety of other trigger factors. Therefore, only qualified teachers can provide the best education to students. So the quality of education is very dependent on the quality of the teacher (Tehseen \& Hadi, 2015). The same thing has been stated by Elliott (2015) in his research that the quality of teacher performance is the single most important school variable that influences student achievement. Learning activities must be designed to achieve the goals correctly. the application of innovative technology, new methods based on cutting-edge technology are highly recommended to be applied by teachers in each of their learning activities and to support their performance (Abdelrazeq, Janssen, Tummel, \& Richert, 2017).

The second finding in this study is the performance of teachers who do not have an educator certificate is still low. This still needs to be improved as the development of quality teachers in Gorontalo Province in the future. Improving teacher performance is very important. Various basic importance of the teacher, through its performance, the teacher plays an important role in implementing the curriculum. A good curricula implication will increase students' knowledge and skills (Dewi \& Djohar, 2018). Thus the teacher quality improvement program is an effort that is needed immediately. Another thing that was highlighted in the findings of this study was that it was lower than the teacher's performance, especially in the implementation core learning activities (see Figure 1). The low ability to manage learning activities is certainly a note for improvement in the future. This is in accordance with the recommendations of Olivia \& Pawlas (2001) regarding learning activities teachers must master six competencies namely: following a systematic approach, following a model of instruction, writing instructional goals and objectives, applying taxonomies of instructional objectives, describing and analyzing learning tasks, and organizing instructional plans. Figure 2 
below presents a comparison of teacher performance in indicators of pre-learning activities between groups of teachers who have certificates and groups of teachers who do not have certificates.

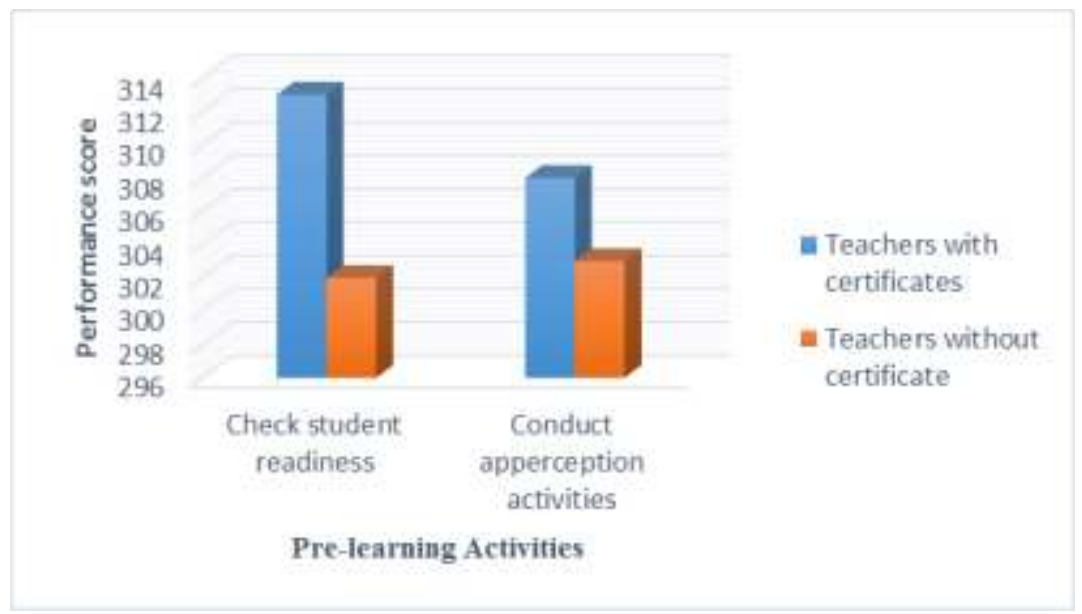

Figure 2

Comparison of Teacher's Performance in Indicators of Pre-Learning Activities

Figure 2 clearly shows information that descriptively the performance of teachers who have certificates is higher than teachers who do not have certificates. Other than that, the results of this study indicate the most distant differences in the ability of teachers to manage core learning activities. In detail, the difference in capability is presented in Figure 3 below.

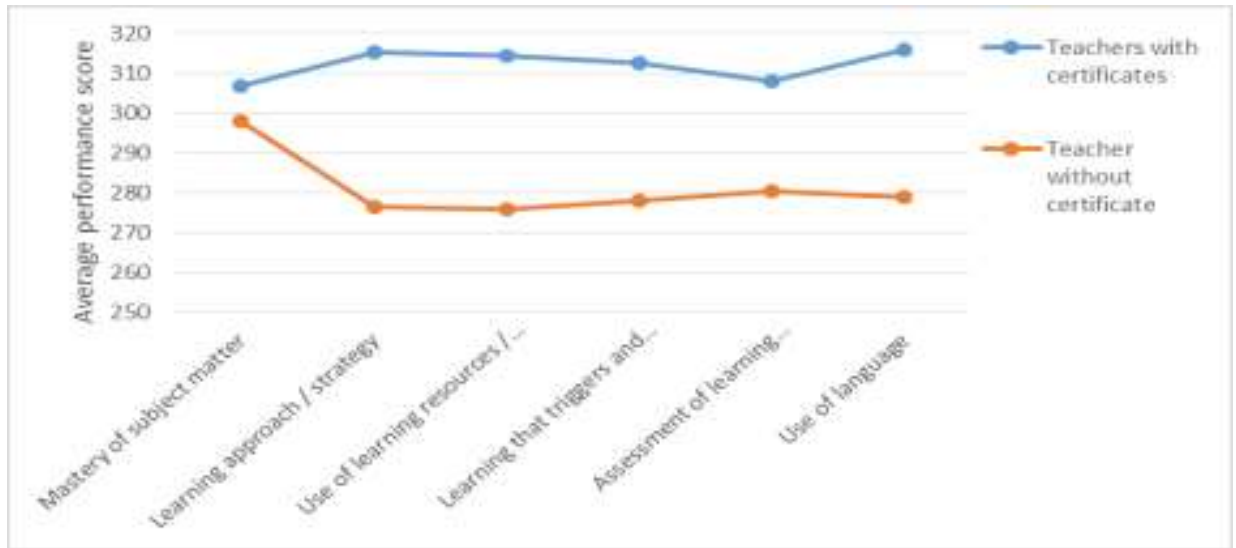

Figure 3

Comparison of Teacher's Ability to Manage Core Learning Activities 
The findings of this study indicate that the performance that most distinguishes between teachers who have certificates and teachers who do not have certificates is in the ability of learning approach / strategy, use of learning media resources / learning, and use of languange. This shows that the superiority of teachers who have an educator certificate is in this aspect of the ability. But generally, it can be explained that the Teacher Certification Program in Gorontalo Province has had a positive impact on improving teacher performance, particularly in the aspects of managing core learning activities. A similar case is also found in the closing activities indicators presented in Figure 4 below.

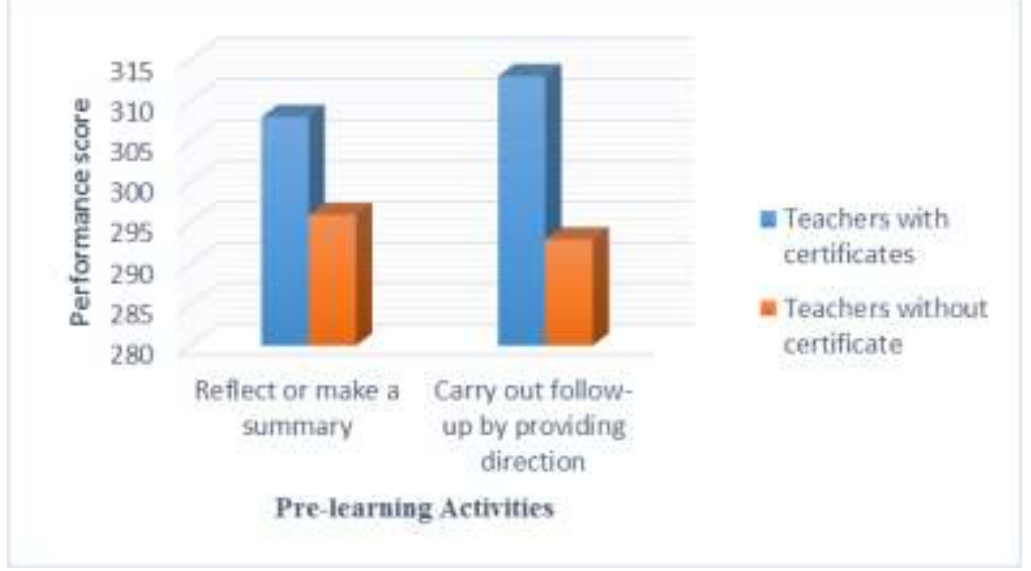

Figure 4

Comparison of Teacher's Performance in Indicators of Closing Activities

Similar to the previous findings on other indicators, the closing activities also shows the high performance of teachers who have educator certificates. Therefore, descriptively it can be stated that teachers with teacher certificates have better performance than teachers who do not have teacher certificates. Every teacher is always required to perform the best performance, especially in learning activities. Teacher performance is very closely related to teacher influenceiveness. Teacher influenceiveness plays an important role in learning activities. Influenceive teachers will help students understand and solve their problems. In addition, influenceive teachers will be able to control and manage their learning activities well (Habib 2017). In this study there were still some teachers who had low performance. This requires guidance for the development of teacher professionalism. Mizell (2010) explains that professional development is a strategy used by schools and government to ensure that educators continue to strengthen their performance, especially in classroom learning practices. This is very important considering the quality of education is strongly influenced by the quality of teachers.

The third finding in this study is related to empirical evidence that there is a significant difference between the performance of teachers who have educator certificates and teachers who do not have an educator certificate. This information is found in the results of inference statistical tests which show that the performance of teachers who have 
educator certificates is significantly higher. The results of this study are supported by the findings of Haryanto et al (2016) that teacher certification policies have an impact on competency and quality of learning which ultimately contributes to student achievement in Indonesia. Through the teacher certification program from the government, we can get satisfactory results in terms of the development of teacher performance in schools. In addition, the teacher certification program is a dream for every teacher because it has an impact on the health of the teacher. This is because certified teachers will receive teaching certificates and professional allowances for the value of certain wages each month. In addition to improving the quality of teacher performance, teacher certification programs in Indonesia also encourage the welfare of teachers with higher incomes. Of course we hope that with the teacher certification program in Indonesia, the teacher's performance will increase to achieve the goal of education in Indonesia, namely to educate the life of the nation.

The findings of this study are also supported by the results of the study of Pardimin \& Huda (2018) that teaching performance could be improved from various factors, one of which is teacher certification. Teacher certification is an educational program held to improve the quality, competence and professionalism of teachers (Hakim, 2018). The results of the study prove that empirically certification can be a supporting factor in increasing teacher performance in learning activities. In addition, Panigrahi (2014) emphasizes that improving the quality of elementary education raises many problems, one of which is the development of teacher quality. Based on this, it is clear that teacher variables play a significant role in improving the quality of education.

Various findings that support the implementation of teacher certification programs in Indonesia. Haryanto et al (2016) explained that the teacher certification policy has contributed to the competence and quality of learning that ultimately contributes to students in Indonesia. Regardless of the benefits of this program, it is certainly realized that this program really needs support from various parties. The government and universities must collaborate synergistically in improving the quality of education. Both parties have a very important role in the education sector especially in improving the quality and competence of teachers in schools (Situmorang, et al., 2019). Universities as tertiary institutions must carry out development and training functions in accordance with the required expertise. In addition, the government acts as a policy maker in supporting the implementation of this program that can run as expected.

Professional development of teachers must also keep up with the times. Teachers need to be supported by creativity and innovation in an effort to improve their performance in the global era like today (Wicaksono, Wasis, \& Madlazim, 2017; Zulkarnaen, Supardi, \& Jatmiko, 2017; Fuad et al, 2019). This is in line with the opinion of Odebode (2018) that learning activities in the 21 st century certainly have different characteristics than before. The development of these technologies has become a teacher's performance challenge where learning can occur anywhere, anytime and any topic that enables students to develop. In addition, the use of modern technology, social media and digitalization must be mastered by the teacher in developing maximum performance. 
Teacher certification is a preparation for the preparation of teachers who have better abilities in learning. This not only increases the performance of teachers in learning, but also supports student learning outcomes. Teacher certification policies can develop more effective education personnel (Hammond et al, 2006). The teacher certification model has increased the motivation of teachers to improve their performance in learning. Improved student learning outcomes (Pacemska, 2012). The results of this study are in line with the findings of this study that teachers who have educator certificates tend to have good performance and good student learning outcomes as well.

Learning models and approaches have a significant effect on increasing student learning outcomes (Peng \& Chen, 2018). As we know that the success of the model and approach is very dependent on the quality of the teacher in learning. This shows the importance of teacher performance in learning. In this study, teachers who have educator certificates show more optimal performance. For this reason, teacher certification programs need support in order to achieve good teacher performance and maximum student learning outcomes.

The certification program is the process of providing educator certificates to teachers who have met certain requirements that aim to improve the quality of teachers and the welfare of teachers (Triyanto, 2012). Efforts to improve teacher quality must be done through planning, implementation, control, and repairs must be carried out by the Education Quality Assurance Center and the Education Quality Assurance Agency in each province. Revitalization of the Quality assurance system at the school level needs to be done to ensure the certification program continues (Prasetyo, 2014). The teacher certification program in Indonesia, especially in Gorontalo Province, is an effort of the government to improve teacher professionalism in general and teacher performance in learning activities specifically. The results of this study have proven the benefits of the program so that it must be maintained or even improved in the future.

\section{CONCLUSION}

Based on the results and discussion of this study, it can be concluded that the performance of teachers who have an educator certificate has shown good results. Another thing found in the group of teachers who do not have an educator certificate shows that the performance has not been maximized and still needs to be improved. Empirically it can be concluded that there are significant differences between teacher performance in learning activities in terms of ownership of the educator's certificate. The teacher certification program in Gorontalo Province has a positive impact on improving teacher performance. This study indicate that the teacher certification program from the government so far has had a positive impact on teacher performance, especially in Gorontalo Province. This means that teachers who are currently not participating in the teacher certification program should be encouraged to participate in the program so that they can improve their abilities in their fields so that the objectives of national education in Indonesia can be achieved well.

Based on the findings and conclusions of this study, it is recommended that the Teacher Certification Program in Gorontalo Province be carried out continuously so that the 
performance of elementary school teachers in Gorontalo Province will be better. In the future, further studies are needed regarding the evaluation of the implementation of the program so that information can be obtained both aspects of success and aspects of obstacles so that positive activities such as this can be improved.

\section{REFERENCES}

Abdelrazeq, A., Janssen, D., Tummel, C., \& Richert, A. S. (2017). Teacher 4.0: Reqruitments of the teacher of the future in context of the fourth industrial revolution. International Technology, Education and Development Conference, 8221-8226. doi. 10.21125/iceri.2016.0880.

Almeida, J. C. D. (2017). Teacher performance evaluation: The importance of performance standards. International Journal for Cross-Disciplinary Subjects in Education (IJCDSE), 8(1), 2973-2981.

Arifin, H. M. (2015). Influence of competence and motivation on teacher performance and primary and secondary education quality at Yapis Education in Jayapura-Indonesia. Australian Journal of Basic and Applied Sciences, 9(3), 630637.

Chetty, R, Friedman, J. N., \& Rockoff, J. E. (2014). Measuring the impacts of teachers II: Teacher value-added and student outcomes in adulthood. American Economic Review, 104(9), 2633-2679. doi:10.1257/aer.104.9.2633.

Dewi, L. P., \& Djohar, A. (2018). The Influence of teacher performance in implementation of the 2013 curriculum toward chemistry learning achievement. IOP Conference Series: Materials Science and Engineering, 1-4. doi. 10.1088/1757899X/335/1/012129.

Elliott, K. (2015). Teacher performance appraisal: More about performance or development? Australian Journal of Teacher Education, 40(9), 102-116. doi. 10.14221/ajte.2015v40n9.6.

Fuad, A. Z., Alfin, J., Fauzan., Astutik, S., \& Prahani, B. K. (2019). Group science learning model to improve collaborative problem solving skills and self-confidence of primary schools teacher candidates. International Journal of Instruction, 12(3), 119132. doi. 10.29333/iji.2019.1238a.

Habib, H. (2017). A study of teacher influenceiveness and its importance. National Journal of Multidisciplinary Research and Development, 2(3), 530-532.

Hakim, L., Tunas, B., Rubini, B. (2018). Evaluation of the professionalism of teachers accomplishing certification program: Evidence from Bekasi City, Indonesia. International Journal of Multidisciplinary Education and Research, 3(4), 32-35.

Hammond, L. D., Holtzman, D. J., Gatlin, S. J., \& Heilig, J. V. (2006). Does teacher preparation matter? Evidence about teacher certification, teach for America, and teacher effectiveness. Stanford University. https://www.nctq.org/nctq/research/1114011196655.pdf. 
Hanushek, E. A. (2011). The economic value of higher teacher quality. Economics of Education Review, 30(3), 466-479. doi:10.1016/j.econedurev.2010.12.006.

Harjantoa, I., Liea, A., Wihardinib, D., Pryorc, L., \& Wilson, M. (2017). Communitybased teacher professional development in remote areas in Indonesia. Journal of Education for Teaching, 1-20. doi. 10.1080/02607476.2017.1415515.

Haryanto, E., Mukminin, A., Murboyono, R., Muazza, M., \& Ekatina, M. (2016). Teacher certification policy: Evidence from students' perception on certified English teachers at one public high school in Jambi Indonesia and policy implications. Turkish Online Journal of Qualitative Inquiry, 7(3), 224-244. doi. 10.17569-tojqi.31703222632.

Jackson, C. K,. Rockoff, J. E., \& Staiger, D. O. (2014). Teacher influences and teacherrelated policies. Annual Review of Economics, 6(1), 801-825. doi:10.1146/annureveconomics-080213-040845.

Loeb, S., \& Page, M. E. (2000). Examining the link between teacher wages and student outcomes: The importance of alternative labor market opportunities and non-pecuniary variation. Review of Economics and Statistics, 82(3), 393-408. doi:10.1162/003465300558894.

Malkab, M., Nawawi, J., Mahmud, A., \& Sujiono, E. H. (2015). The implementer disposition of teacher certification policy in Indonesia. International Education Studies, 8(5), 54-61. doi. 10.5539/ies.v8n5p54.

Mizell, H. (2010). Why professional development matters. Oxford: Learning Forward.

Nurmalia, P., \& Kusumawardhani. (2017). Does teacher certification program lead to better quality teachers? Evidence from Indonesia. Education Economics, 25(6), 590 618. doi. 10.1080/09645292.2017.1329405.

Odebode, A. A. (2018). Influence of psychosocial factors on job performance of female teachers in Kwara State, Nigeria. International Journal of Instruction, 11(3), 233-248. doi. 10.12973/iji.2018.11317a.

Olivia, P., \& Pawlas G. (2001). Supervision for today's schools. New York: Wiley \& Sons.

Pacemska, T. A. (2012). Improving learning outcomes in literacy and numeracy: the experience of the former Yugoslav Republic of Macedonia. UNICEF.

Panigrahi, M. R. (2014). School influenceiveness at primary level of education in relation to classroom teaching. International Journal of Instruction, 7(2), 51-64.

Pardimin, \& Huda, M. (2018). Investigating factors influencing mathematics teaching performance: An empirical study. International Journal of Instruction, 11(3), 391-402. doi. 10.12973/iji.2018.11327a. 
Peng, M. T. P., \& Chen, C. C. (2018). The effect of instructor's learning modes on deep approach to student learning and learning outcomes. Educational Sciences: Theory \& Practice, 19(3),65-85. doi. 10.12738/estp.2019.3.005.

Prasetyo, H. E. (2014). Teacher continuous quality improvement after certification program. Indonesian Journal of Curriculum and Educational Technology Studies, 3(1), $1-6$.

Schacter, J. (2005). Teacher performance-based accountability: Why, what and how. Santa Monica: Milken Family Foundation.

Situmorang, M., Gultomb, S., Hamid, A., Panjaitan, A. M., \& Ritonga, W. (2019). University-government collaboration model to improve school teacher competence in North Sumatra, Indonesia. International Journal of Training Research, 1-18. doi. 10.1080/14480220.2018.1576324.

Suryadi, A., Rasjidi, U., \& Budimansyah, D. (2017). Does teaching licensure boost student learning? Indonesia's answer. The New Educational Review, 261-270. doi. 10.15804/tner.2017.49.3.21.

Tehseen, S., \& Hadi, N. U. (2015). Factors influencing teachers' performance and retention. Mediterranean Journal of Social Sciences, 6(1), 233-244. doi. 10.5901/mjss.2015.v6n1p233.

Triyanto. (2012). Improving teacher profesionalism through certification program: An Indonesia case study. International Journal of Educational and Pedagogical Sciences, 6(7), 1868-1872.

Villegas-Reimers, E. (2003). Teacher professional development: an internasional review of literature. Paris: International Institute for Educational Planning.

Wenno, I. H. (2017). Influence of principal managerial leadership and compensation towards physics teacher performance in senior high school in Baguala. International Education Studies, 10(1), 233-244. doi. 10.5539/ies.v10n1p233.

Wicaksono, I., Wasis, \& Madlazim. (2017). The influenceiveness of virtual science teaching model (VS-TM) to improve student's scientific creativity and concept mastery on senior high school physics subject. Journal of Baltic Science Education, 16(4), 549-561.

Zulkarnaen, Supardi, Z. A. I, \& Jatmiko, B. (2017). Feasibility of creative exploration, creative elaboration, creative modeling, practice scientific creativity, discussion, reflection (C3PDR) teaching model to improve students' scientific creativity of junior high school. Journal of Baltic Science Education, 16(6), 1020-1034. 